\section{Decay Kinetics of Toluene Phytoremediation Stimulation}

\author{
Kwang Jin Kim and Eun Ha Yoo \\ Urban Agriculture Research Division, National Institute of Horticultural and \\ Herbal Science, Rural Development Administration, Suwon 441-440, Korea
}

Stanley J. Kays ${ }^{1}$

Department of Horticulture, 1111 Plant Sciences Building, University of Georgia, Athens, GA 30602-7273

Additional index words. volatile organic compounds, VOCs, health

\begin{abstract}
Begonia maculata, Ardisia crenata, and Ardisia japonica plants exposed to 3.5 ppm toluene in air for $12 \mathrm{~h}$ displayed a pronounced stimulation $(358 \%, 318 \%$, and $\mathbf{2 5 2} \%$, respectively) in subsequent toluene removal potential. The duration of the stimulation effect, monitored over 3 weeks, was short-lived decaying to prestimulation levels within 1 to 7 days depending on species. Elevated phytoremediation rate was dependent on the continued presence of toluene. The rapid rate of increase in phytoremediation and subsequent decay points toward a response mediated by changes in gene expression by the plant, microorganisms within the media, or both rather than an alteration in microbe population. A better understanding of the stimulation response may facilitate the use of plants for indoor air remediation in homes and offices.
\end{abstract}

Indoor plants have the ability to remove various volatile organic compounds (VOCs) (Table 1) and may be useful for remediating the air in homes and offices, reducing the potential deleterious health effects on persons exposed. The phytoremediation effect is the result of both the plant and associated microorganisms in the media (Chun et al., 2010; Orwell et al., 2004; Son et al., 2000; Wolverton, 1986; Wolverton and Wolverton, 1993; Wood et al., 2002), the latter being the primary contributor to VOC removal during the night (Kim et al., 2008). Removal efficiency is known to vary widely among plant species, the VOC in question, and other factors (Kays, 2011).

The U.S. Environmental Protection Agency (EPA) reported detection of more than 900 VOCs in the air of public buildings (EPA, 1989) and in a Finnish study (Kostiainen, 1995), over 200 VOCs were identified in each of 26 homes. Toluene is a highly toxic VOC commonly found as a component of indoor air, the presence of which can represent a serious health hazard. It is readily absorbed through the respiratory tract and to a lesser extent through the skin (EPA, 1990). Exposure to high levels is known to affect the kidneys, nervous system, liver, brain, and heart. Short-term exposure of humans to toluene (100 ppm v/v or greater) has elicited central nervous system effects such as fatigue, confusion, poor coordination, impairment of reaction time, perception, and motor control and function (NTP, 2000) in addition

Received for publication 19 Mar. 2012. Accepted for publication 15 May 2012.

${ }^{1}$ To whom reprint requests should be addressed; e-mailkaysstan@uga.edu. to poor performance on cognitive tests and eye and upper respiratory tract irritation (ATSDR, 1989).

We recently demonstrated that the removal efficiency of plants for toluene increased rapidly and markedly with their exposure to the gas (1.3 ppm for $18 \mathrm{~h}$ ) (Kim et al., 2011). Of the 28 crops tested, 27 displayed an increase in toluene removal efficiency after the initial exposure with the greatest increase occurring after the first exposure. The increase in efficiency between the first and third exposure ranged from $378 \mu \mathrm{g} \cdot \mathrm{m}^{-3} \cdot \mathrm{h}^{-1} \cdot \mathrm{m}^{-2}$ leaf area in Pinus densiflora Siebold \& Zacc. to -16.6 in Salvia elegans Vahl (mean for all crops, $156 \mu \mathrm{g} \cdot \mathrm{m}^{-3} \cdot \mathrm{h}^{-1} \cdot \mathrm{m}^{-2}$ ) with a maximum increase of over $600 \%$.

Increasing the efficiency of toluene removal in particular and VOCs in general from indoor air is highly advantageous and could facilitate developing a horticultural solution to a serious health problem. Because a better understanding of the mechanism(s) involved may improve use of the response for practical applications, we determined the duration of the toluene stimulation effect on phytoremediation efficiency.

\section{Materials and Methods}

Plant materials. Begonia maculata Raddi, a herbaceous foliage plant, and Ardisia crenata Sims. and Ardisia japonica (Thumb.) Blume, woody foliage plants, were obtained from a commercial market. The plants were transplanted into pots containing a uniform growing medium comprised of Mix \#4 (Sun Gro Horticulture, Bellevue, WA), bark-humus (Biocom. Co., Seoul, Korea), and sand at $5: 1: 1, \mathrm{v} / \mathrm{v} / \mathrm{v}$. Mix \#4 contained Canadian sphagnum peatmoss ( $55 \%$ to $65 \%$ by volume),

Table 1. Volatile organic compounds that have been shown to be removed from air by plants.

\begin{tabular}{|c|c|}
\hline Volatile & Source \\
\hline$\overline{\text { Acetone }}$ & $\begin{array}{l}\text { Oyabu et al., 2003; } \\
\text { Tani and Hewitt, } 2009\end{array}$ \\
\hline Benzaldehyde & Tani and Hewitt, 2009 \\
\hline Benzene & $\begin{array}{l}\text { Cornejo et al., 1999; Liu et al., } \\
\text { 2007; Orwell et al., 2004; Tarran } \\
\text { et al., 2007; Wolverton, 1986; Yang } \\
\text { et al., 2009; Yoo et al., } 2006\end{array}$ \\
\hline iso-Butyraldehyde & Tani and hewitt, 2009 \\
\hline$n$-Butyraldehyde & Tani and hewitt, 2009 \\
\hline Crotonaldehyde & Tani and hewitt, 2009 \\
\hline Diethyl ketone & Tani and hewitt, 2009 \\
\hline Formaldehyde & $\begin{array}{l}\text { Aydongan and Montoya, 2011; Chen } \\
\text { et al., 2010; Kim et al., 2008, 2010; } \\
\text { Oyabu et al., 2003; Sawada and } \\
\text { Oyabu, 2008; Son et al., 2000; } \\
\text { Wolverton, 1986; Wolverton and } \\
\text { Wolverton, 1984; Xu et al., } 2011\end{array}$ \\
\hline Methacrolein & Tani and Hewitt, 2009 \\
\hline Methyl ethyl ketone & Tani and Hewitt, 2009 \\
\hline Methyl isobutyl ketone & Tani and Hewitt, 2009 \\
\hline Methyl iso-propyl ketone & Tani and Hewitt, 2009 \\
\hline Methyl $n$-propyl ketone & Tani and Hewitt, 2009 \\
\hline Octane & Yang et al., 2009 \\
\hline Pentane & Cornejo et al., 1999 \\
\hline$\alpha$-Pinene & Yang et al., 2009 \\
\hline Propionaldehyde & Tani and Hewitt, 2009 \\
\hline Toluene & $\begin{array}{l}\text { Cornejo et al., 1999; Kim et al., 2011; } \\
\text { Orwell et al., 2006; Sawada and } \\
\text { Oyabu, 2008; Yang et al., 2009; } \\
\text { Yoo et al., } 2006\end{array}$ \\
\hline Trichloroethylene & Wolverton, 1986; Yang et al., 2009 \\
\hline Xylene & $\begin{array}{l}\text { Cornejo et al., 1999; Orwell et al., } \\
\text { 2004; Sawada and Oyabu, } 2008 \text {; } \\
\text { Wolverton and Wolverton, } 1993\end{array}$ \\
\hline
\end{tabular}


perlite, dolomitic lime, gypsum, and a wetting agent. The plants were grown in a greenhouse for greater than 1 month after transplanting.

The plants were watered every $3 \mathrm{~d}$ with the excess water allowed to drain. All plants were watered the day before the gas treatments. Five pots (19-cm diameter with media volume of $2.2 \mathrm{~L}$ ), each containing one or more plants (subsequently referred to as a plant), were placed in a chamber with a light intensity of $60 \pm 2 \mu \mathrm{mol} \cdot \mathrm{m}^{-2} \cdot \mathrm{s}^{-1}$ using fluorescent lights and a $12-\mathrm{h}$ photoperiod.

Three replicates (chambers) of each species were tested. Chambers without plants were used to determine toluene losses not resulting from the plants (e.g., leakage, adsorption, chemical reactions). Plant height was measured and leaf area determined using a LI-3100 leaf area meter (LI-COR Inc., Lincoln, NE) at the end of the experiment.

Treatment system. The treatment system consisted of controlled-environment rooms containing the test chambers and a gas generator. The rooms controlled the temperature, light intensity, and relative humidity. The test chambers, as described by Kim et al. (2011), were $1.0 \mathrm{~m}^{3}(90 \mathrm{~cm}$ wide $\times 90 \mathrm{~cm}$ long $\times$ $123 \mathrm{~cm}$ high) and impervious to VOCs. Interior air was circulated $\left(6 \mathrm{~L} \cdot \mathrm{min}^{-1}\right)$ and tested for toluene concentration at three locations, 12,70 , and $98 \mathrm{~cm}$ above the bottom of the chamber.

Gas exposure and measurement. Toluene gas $(1.2 \mathrm{~L})$ was introduced into each test chamber with the plants present, as previously described (Kim et al., 2011), and allowed to equilibrate within the chamber for $15 \mathrm{~min}$. The internal concentration was determined and corrected to $3.5 \mathrm{ppm}$ $\left(13,181 \mu \mathrm{g} \cdot \mathrm{m}^{-3}\right)$ for the stimulation treatment. The plants remained in the stimulation treatment for $12 \mathrm{~h}$ and then were moved to fresh air for $12 \mathrm{~h}$. After the stimulation treatment, the subsequent toluene removal rate by the plants was determined at $0,1,2$, and 3 weeks after stimulation. Each test date included three replications of five individual plants for a total of 75 plants plus controls (i.e., plants that were not exposed to the toluene stimulation treatment) for each species. Time 0 was after $12 \mathrm{~h}$ in fresh air after the toluene stimulation treatment ended. The plants were exposed a $1.3 \mathrm{ppm}$ $\left(4896 \mu \mathrm{g} \cdot \mathrm{m}^{-3}\right)$ and the rate of toluene removal measured within the chambers after 6 and $12 \mathrm{~h}$ as previously described (Kim et al., 2011). Changes in toluene concentration within the chambers were expressed as cumulative removal $\left(\mu \mathrm{g} \cdot \mathrm{m}^{-3} \cdot \mathrm{m}^{-2}\right.$ leaf area) and as removal rate $\left(\mu \mathrm{g} \cdot \mathrm{m}^{-3} \cdot \mathrm{h}^{-1} \cdot \mathrm{m}^{-2}\right.$ leaf area). $B$. maculata and $A$. japonica were also tested at $0,1,3,5$, and $7 \mathrm{~d}$ after exposure. Chambers devoid of plants were treated similarly to determine gas losses resulting from chamber effects.

Toluene quantification. Air samples were collected at the appropriate time intervals using a quartz cold trap [120 mm long, $2.9 \mathrm{~mm}$ o.d., $1.0 \mathrm{~mm}$ i.d. (inlet), $2.0 \mathrm{~mm}$ i.d. (outlet); Markes International Ltd., Llantrisant,
U.K.] connected to each chamber with the air collected for $5 \mathrm{~min}$ at $5 \mathrm{~mL} \cdot \mathrm{min}^{-1}$. An automated thermal desorption system with Air Server autosampler (UNITY; Markes International Ltd.) was connected to the injection port of the gas chromatograph-mass spectroscopy (TRACE DSQ; Thermo Electron Co., Waltham, MA). The desorbed sample was cryofocused at $5{ }^{\circ} \mathrm{C}$ for $5 \mathrm{~min}$ on the first few centimeters of the column, desorbed at $280{ }^{\circ} \mathrm{C}$, and separated using a ZB-624 capillary column $(30-\mathrm{m}$ length $\times 0.25-\mathrm{mm}$ i.d., $1.40-\mu \mathrm{m}$ film thickness of $6 \%$ cyanopropylphenyl, 94\% dimethylpolysiloxane; Phenomenex, Torrance, CA). The injection port temperature was $180{ }^{\circ} \mathrm{C}$ with a split ratio of $29: 1$. Helium was used as the carrier gas at a flow rate of $1.0 \mathrm{~mL} \cdot \mathrm{min}^{-1}$. The column temperature was held at $45^{\circ} \mathrm{C}$ for $1 \mathrm{~min}$ and increased at a rate of $15^{\circ} \mathrm{C} \cdot \mathrm{min}^{-1}$ to $100{ }^{\circ} \mathrm{C}$ and held for $1 \mathrm{~min}$ and then increased at a rate of $5^{\circ} \mathrm{C} \cdot \mathrm{min}^{-1}$ to $135^{\circ} \mathrm{C}$.

Data analysis. Gas concentrations were expressed as $\mu \mathrm{g} \cdot \mathrm{m}^{-3}$ with the data normalized to $24 \pm 1{ }^{\circ} \mathrm{C}$ and $100 \mathrm{kPa}$ (Hines et al., 1993). Data were expressed as the average of three replicates. The accumulated removal of toluene per unit leaf area [Eq. 1] and the removal efficiency per unit leaf area and time [Eq. 2] were calculated (Kim et al., 2008, 2011) as:

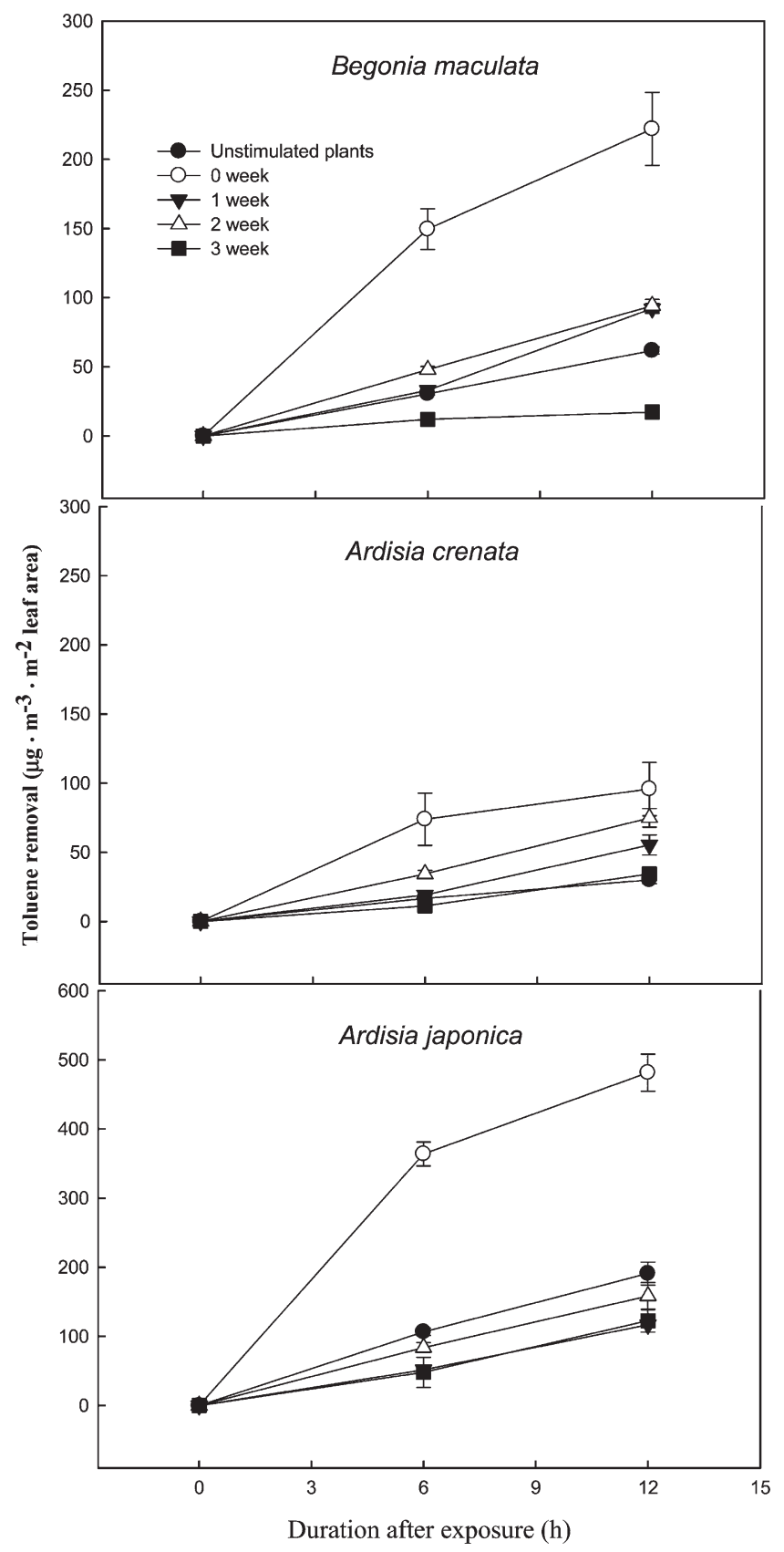

Fig. 1. Accumulated removal of toluene ( $1.3 \mathrm{ppm}$ in air) by potted plants as affected by the length of time after the initial toluene stimulation treatment. Unstimulated plants were not exposed to the stimulation treatment; 0 time indicates assessment of toluene removal rate $12 \mathrm{~h}$ after the simulation treatment. 


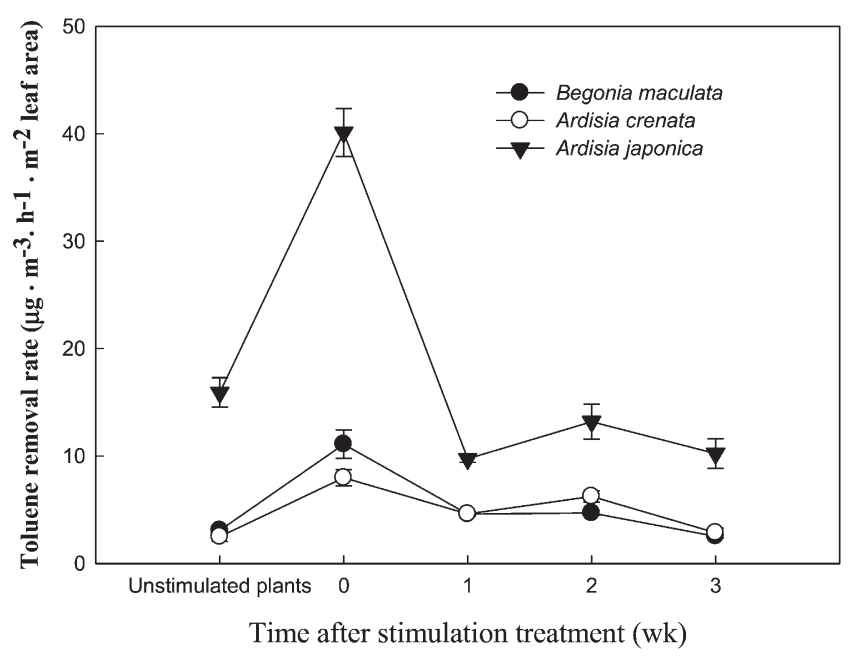

Fig. 2. Changes in the subsequent toluene ( $1.3 \mathrm{ppm}$ in air) removal rate by potted plants as affected by the length of time ( 0 to 3 weeks) after the initial toluene stimulation treatment. Unstimulated plants were not exposed to the stimulation treatment; 0 time indicates assessment of toluene removal rate $12 \mathrm{~h}$ after the simulation treatment.

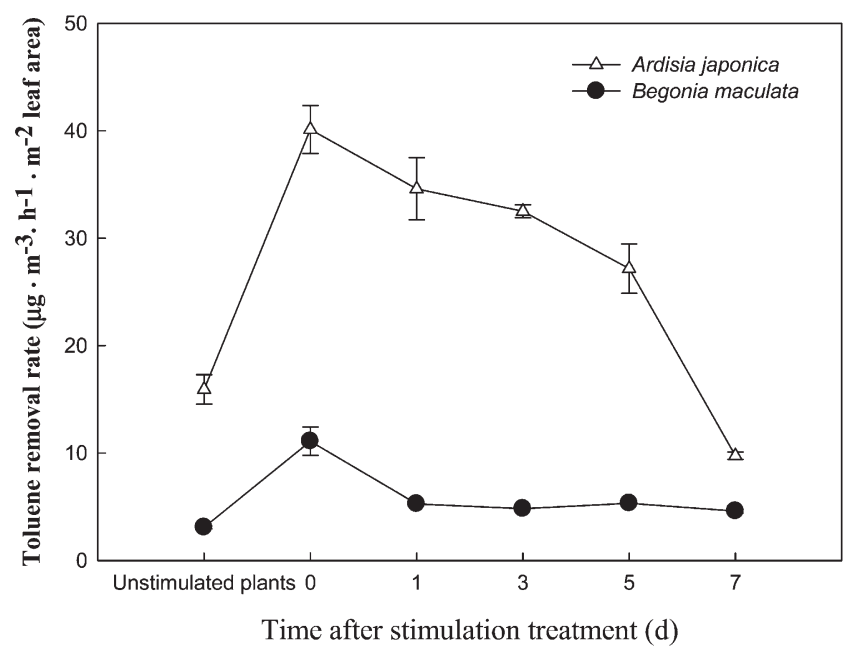

Fig. 3. Changes in toluene ( $1.3 \mathrm{ppm}$ in air) removal rate by potted plants as affected by the length of time ( 0 to $7 \mathrm{~d}$ ) after initial toluene stimulation pretreatment. Unstimulated plants were not exposed to the stimulation treatment; 0 time indicates assessment of toluene removal rate $12 \mathrm{~h}$ after the simulation treatment.

(a) Accumulated removal $=$

$$
\begin{aligned}
& {[(\mathrm{Pi}-(\mathrm{Ci}-\mathrm{C}))-\mathrm{P}]} \\
& \times(\mathrm{F} \times \mathrm{CV}) / \mathrm{L}
\end{aligned}
$$

(b) Removal efficiency $=$

$$
\begin{aligned}
& {[(\mathrm{Pi}-(\mathrm{Ci}-\mathrm{C}))-\mathrm{P}]} \\
& \times(\mathrm{F} \times \mathrm{CV}) /\left(\begin{array}{lll}
\mathrm{L} & \times \mathrm{T}
\end{array}\right)
\end{aligned}
$$

where $\mathrm{P}$ is the gas concentration measured in a chamber with plants $\left(\mu \mathrm{L} \cdot \mathrm{L}^{-1}\right)$; Pi the initial gas concentration measured in a chamber with plants $\left(\mu \mathrm{L} \cdot \mathrm{L}^{-1}\right)$; $\mathrm{C}$ the gas concentration measured in a chamber without plants $\left(\mu \mathrm{L} \cdot \mathrm{L}^{-1}\right) ; \mathrm{Ci}$ the initial gas concentration measured in a chamber without plants $\left(\mu \mathrm{L} \cdot \mathrm{L}^{-1}\right) ; \mathrm{F}$ the toluene conversion factor for volume $\left(\mu \mathrm{L} \cdot \mathrm{L}^{-1}\right)$ to mass $\left(\mathrm{mg} \cdot \mathrm{m}^{-3}\right) ; \mathrm{CV}$ the volume of the chamber $\left(\mathrm{m}^{3}\right)$; $\mathrm{L}$ the total leaf area per chamber $\left(\mathrm{m}^{2}\right)$; and $\mathrm{T}$ the gas exposure time $(\mathrm{h})$.
The loss of toluene $(\mathrm{Ci}-\mathrm{C})$ not resulting from the plant and media was determined using empty chambers.

\section{Results and Discussion}

The actual toluene removal rate of $B$. maculata, A. crenata, and A. japonica increased $358 \%, 318 \%$, and $252 \%$, respectively, after the initial exposure to toluene. When expressed as accumulated removal on a mass per unit leaf area $\left(\mu \mathrm{g} \cdot \mathrm{m}^{-3} \cdot \mathrm{m}^{-2}\right)$ basis, $B$. maculata and $A$. japonica displayed substantially higher increases in phytoremediation as a result of the initial toluene exposure (stimulation treatment) than $A$. crenata, which had a modest although statistically significant effect (Fig. 1). Each species progressively removed subsequent toluene over the 12-h test period. With the exception of plants that were re-exposed immediately after the initial stimulation exposure ( 0 time), there were only small differences by 1,2 , or 3 weeks, indicating that the stimulation of toluene removal declines fairly rapidly, essentially reaching pre-exposure phytoremediation rates by 1 week. Assessing changes in the simulation of toluene removal efficiency, expressed as $\mu \mathrm{g} \cdot \mathrm{m}^{-3} \cdot \mathrm{h}^{-1} \cdot \mathrm{m}^{-2}$ leaf area, the decline in the initial increase in efficiency was striking, essentially reverting back to base levels (unstimulated control plants) within the first week (Fig. 2). The decline was most pronounced in A. japonica, which had the highest overall removal rate of the three species.

In subsequent tests in which the decline in the initial increase in toluene removal efficiency was assessed over a 7-d period, the timing of the decline was more precisely illustrated (Fig. 3). The decay in the stimulation response varied depending on the plant species tested. B. maculata declined essentially back to the initial prestimulation rate in a single day, whereas $A$. japonica declined progressively over the entire week. The cause of the difference in the rate of loss of the stimulation response between species is not clear. Based on the rapidity of the response, it is highly probable that the stimulation in phytoremediation efficiency with the initial exposure to toluene was the result of changes in gene expression, although whether it was the result of changes in the plant, microorganisms in the media, or both is not known.

From a practical standpoint, the stimulation in phytoremediation requires continual exposure to toluene so preconditioning the plants before sale would at this time appear to be of no apparent value. It is significant, however, that the plants can very rapidly alter their metabolism in response to the chemistry of the surrounding air, greatly increasing their phytoremediation effectiveness. In addition to toluene, a stimulation in phytoremediation efficiency has been shown for benzene (Orwell et al., 2004) and formaldehyde (Kil et al., 2008), the latter being structurally very dissimilar from benzene and toluene.

It is evident that in closed systems, certain plant species can effectively remove a crosssection of VOCs; however, how effectively this translates to real-world situations in which there is a continual flux of VOCs being released into and escaping from the air in homes and offices remains to be seen. Maximizing the VOC removal efficiency of plants will help to expand the range of situations in which plants can be effectively used.

\section{Literature Cited}

ATSDR. 1989. Toxicological profile for toluene. Agency for Toxic Substance and Disease Registry, Atlanta, GA.

Aydongan, A. and L.D. Montoya. 2011. Formaldehyde removal by common indoor plant species and various growing media. Atmos. Environ. 45:2675-2682.

Chen, L., H. Yurimoto, K. Li, I. Orita, M. Akita, N. Kato, Y. Sakai, and K. Izui. 2010. Assimilation of formaldehyde in transgenic plants due to the introduction of the bacterial ribulose 
monophosphate pathway genes. Biosci. Biotechnol. Biochem. 74:627-635.

Chun, S.-C., M.H. Yoo, Y.S. Moon, M.H. Shin, K.-C. Son, I.-M. Chung, and S.J. Kays. 2010. Effect of bacterial population from rhizosphere of various foliage plants on removal of indoor volatile organic compounds. Kor. J. Hort. Sci. Technol. 28:476-483.

Cornejo, J.J., F.G. Munoz, C.Y. Ma, and A.J. Stewart. 1999. Studies on the decontamination of air by plants. Ecotoxicology 8:311-320.

EPA. 1989. Report to Congress on indoor air quality. Vol. II: Assessment and control of indoor air pollution. EPA/400/1-89/001C.

EPA. 1990. Drinking water criteria document for toluene. Environmental Assessment Office, Office of Health and Environmental Assessment, U.S. Environmental Protection Agency, Cincinnati, $\mathrm{OH}$.

Hines, A.L., T.K. Ghosh, S.K. Loylka, and R.C. Warder, Jr. 1993. Indoor air: Quality and control. Prentice Hall, Englewood Cliffs, NJ.

Kays, S.J. 2011. Phytoremediation of indoor airCurrent state of the art, p. 3-21. In: Kim, K.J. (ed.). The value creation of plants for future urban agriculture. Nat. Inst. Hort. Herbal Science, RDA, Suwon, Korea.

Kil, M.J., K.J. Kim, C.H. Pak, H.H. Kim, and Y.W. Lim. 2008. Effects of growing media and exposure frequency on the volatile formaldehyde removal in potted Epipremnuma ureum. Kor. J. Hort. Sci. Technol. 26:325-330.

Kim, K.J., M.I. Jeong, D.W. Lee, J.S. Song, H.D. Kim, E.H. Yoo, S.J. Jeong, S.Y. Lee, S.J. Kays, Y.W. Lim, and H.H. Kim. 2010. Variation in formaldehyde removal efficiency among indoor plant species. HortScience 45:1489-1495.

Kim, K.J., M.J. Kil, J.S. Song, E.H. Yoo, K.C. Son, and S.J. Kays. 2008. Efficiency of volatile formaldehyde removal by indoor plants:
Contribution of aerial plant parts versus the root-zone. J. Amer. Soc. Hort. Sci. 133:1-6.

Kim, K.J., E.H. Yoo, M.I. Jeong, J.S. Song, S.Y. Lee, and S.J. Kays. 2011. Changes in the phytoremediation potential of indoor plants with exposure to toluene. HortScience 46:1646-1649.

Kostiainen, R. 1995. Volatile organic compounds in the indoor air of normal and sick houses. Atmos. Environ. 29:693-702.

Liu, Y.J., Y.J. Mu, Y.G. Zhu, H. Ding, and N.C. Arens. 2007. Which ornamental plant species effectively remove benzene from indoor air? Atmos. Environ. 41:650-654.

NTP. 2000. Toxicology and carcinogenesis studies of toluene in $\mathrm{F} 344 / \mathrm{N}$ rats and $\mathrm{B} 6 \mathrm{C} 3 \mathrm{~F}_{1}$ mice (inhalation studies). Technical Rept. Series No. 371, National Toxicology Program, National Institutes of Health, U.S. Department of Health and Human Service, Public Health Service, Research Triangle Park, NC.

Orwell, R.L., R.L. Wood, M.D. Burchett, J. Tarran, and F. Torpy. 2006. The potted-plant microcosm substantially reduces indoor air VOC pollution: II. Laboratory study. Water Air Soil Pollut. 177:59-80.

Orwell, R.L., R.L. Wood, J. Tarran, F. Torpy, and M.D. Burchett. 2004. Removal of benzene by the indoor plant/substrate microcosm and implications for air quality. Water Air Soil Pollut. 157:193-207.

Oyabu, T., A. Sawada, T. Onodera, K. Takenaka, and B. Wolverton. 2003. Characteristics of potted plants for removal of offensive odors. Sens. Actuators B Chem. 89:131-136.

Sawada, A. and T. Oyabu. 2008. Purification characteristics of pothos for airborne chemicals in growing conditions and its evaluation. Atmos. Environ. 42:594-602.

Son, K.C., S.H. Lee, S.G. Seo, and J.E. Song. 2000. Effects of foliage plants and potting soil on the absorption and adsorption of indoor air pollutants. J. Korean Soc. Hort. Sci. 41:305310 .

Tani, A. and C.N. Hewitt. 2009. Uptake of aldehydes and ketones at typical indoor concentrations by houseplants. Environ. Sci. Technol. 43:83388343.

Tarran, J., F. Torpy, and M. Burchett. 2007. Use of living pot-plants to cleanse indoor air-Research review. Proc. Sixth Intern. Conf. on Indoor Air Quality, Ventilation \& Energy Conservation in Buildings-Sustainable Built Environment, Sendai, Japan.

Wolverton, B.C. 1986. Houseplants, indoor air pollutants, and allergic reactions. Rept., National Aeronautics Space Administration, Stennis Space Center, MS.

Wolverton, B.C., R.C. McDonald, and E.A. Watkins, Jr. 1984. Foliage plants for removing indoor air pollution from energy-efficient homes. Econ. Bot. 38:224-228.

Wolverton, B.C. and J.D. Wolverton. 1993. Plants and soil microorganisms: Removal of formaldehyde, xylene, and ammonia from the indoor environment. J. Miss. Acad. Sci. 38:11-15.

Wood, R.A., R.L. Orwell, J. Tarran, F. Torpy, and M Burchett. 2002. Potted-plant/growth media interactions and capacities for removal of volatiles from indoor air. J. Hort. Sci. Biotechnol. 77:120 129.

Xu, Z., L. Wang, and H. Hou. 2011. Formaldehyde removal by potted plant-soil systems. J. Hazard. Materials 192:314-318.

Yang, D.S., S.V. Pennisi, K.C. Son, and S.J. Kays. 2009. Screening indoor plants for volatile organic pollutant removal efficiency. HortScience 44:1377-1381.

Yoo, M.H., Y.J. Kwon, K.C. Son, and S.J. Kays. 2006. Efficacy of indoor plants for the removal of single and mixed volatile organic pollutants and physiological effects of the volatiles on the plants. J. Amer. Soc. Hort. Sci. 131:452-458. 